\title{
LVII. Tabular corrections for the rise and fall of the mercury in the common barometer
}

\section{E. Walker Esq.}

To cite this article: E. Walker Esq. (1812) LVII. Tabular corrections for the rise and fall of the mercury in the common barometer , Philosophical Magazine Series 1, 40:175, 330-332, DOI: $10.1080 / 14786441208638242$

To link to this article: http://dx.doi.org/10.1080/14786441208638242

里 Published online: 27 Jul 2009.

Submit your article to this journal $₫$

Џ Article views: 2

Q View related articles $\square$ 
there is no aperture delineated, and it might be conceived hermetically sealed. Mr. Leslie has introduced a cork, and his figure certainly differs from those in the two editions of Van Helmont which are found in the library of the College of Edinburgh, and which are perfectly alike. Fig. 4. is copied from the edition of 1652 .

Mr. Leslie bas not noticed a sentence immediately following that to which he has referred, in which the principle of the differential thermometer is described. I shall supply his deficiency : "Applicatur vasi A aliquis calor, excedens temperiem ambientis : tunc enim aër inclusus, se dilatabit, secundum plus aut minus caloris, ac juxta, atque excedit veram aëris temperiem clausi in vase $D$, contra quem propellens aquam BC destruet aquilibrium per nimiam actionem. Ita quod in $D$ erit compressus et condensatus aër, per restrictionem : ut cedat dilatationi factæx in A."

It appears from these facts that Sir H. Davy is fully justified in saying that a curious instrument like the differential thermometer is described by Van Helmoñt, " which appears to have been the first in which the expansive power of heated air was exhibited by its action upon cold air."

I shall not pretend to determine whether Mr. Leslie has not read this last passage, or whether he has read it and has not thought proper to quote it: nor shall I offer any observations on insinuations so unwarrantably and unjustly brought forward by the Professor: as the ground for them has been removed, they will fall of course.

Edinburgh, Oct. 20, 1812.

$$
\text { I am, sir, yours, \&c. }
$$

A. B.

1.VII. Talular Corrections for the Rise and Fall of the Mercury in the common Barometer. By E. WALKER, Esqu.

\section{To Mr. Tilloch.}

SIR, No meteorological instrument is in higher estimation that the Barometer. But barometers of the common construction, with an upright tube and open cistern, are not sufficiently correct for investigating the laws of meteozology with the greatest precision, in consequence of the quicksilver's rising or falling in the cistern with every variation in the pressure of the atmosphere. In the best harumeters, however, this imperfection is corrected by 
some mechanical contrivance; but none of these can be added to an instrument, without adding to its price.

But this imperfection may be removed, without any additional apparatus or expense; for we need only find how hight the surface of the mercury in the cistern would be raised by any given fall in the tube, to find the correction for every other point in the scale.

Suppose it were required to find the correction for one inch rise of the quicksilver above the zero, or that point in the scale where no correction is necessary: Let $a=$ the diameter of the cistern, and $l=$ the inside diameter of the tube; then, as equal cylinders have their altitudes reciprocally as their bases, we have $a a: b b:: 1: \frac{b b}{a a}$, which is the correction to be added to the altitude of the column of quicksilver, when it rises one inch above the zero, and subtracted from the altitude of the column, when its surface falls one inch below that point.

Example.-Suppose the inside diamieter of the tube be $\frac{2}{10}$ of an inch, and the diameter of the cistern be two inches $=\frac{20}{10}:$ Then $\frac{4}{400}=\cdot 01=$ the correction for one inch rise or fall of the mercury in the tube.

Suppose the barometer needs no correction, when the surface of the quicksilver stands at 29.5 on the scale, then the corrections for the whole scale, according to the preceding example, would be as in Table 1.

But Mr. De Luc observes, that the cistern barometer does not give the true pressure of the atmosphere; the quicksilver in it being a little depressed on the same principle as in capillary tubes. It is therefore thought necessary, where so much nicety is required, to determine by experiment how wuch the quicksilver is depressed in tubes of a given bore, and to allow accordingly. By some experiments which have been nuade on this stuject by Lord Charles Cavendish, the depression appears to be 067 of an inch for a tube whose inside diameter is $0 \cdot 2$.*

Now, if $\cdot 067$ be added to each of the corrections in Table 1. we shall have the corrections in Tabbe 8.

- Plilos. Trans. vol. lxvi. for the year 1776. 


\begin{tabular}{|c|c|c|c|c|}
\hline \multicolumn{2}{|c|}{ TaBLe 1} & \multicolumn{3}{|c|}{ TaBLE 2} \\
\hline $\begin{array}{l}\text { Alt. in } \\
\text { fnches. }\end{array}$ & $\begin{array}{c}\text { Correc. } \\
\text { tioas. }\end{array}$ & $\begin{array}{l}\text { Alt, in } \\
\text { Inches. }\end{array}$ & & $\begin{array}{l}\text { Correc- } \\
\text { tions. }\end{array}$ \\
\hline $30 \cdot 5$ & +.01 & $30 \cdot 5$ & + & $\cdot 077$ \\
\hline $30^{*}$ & +.005 & $30^{\circ}$ & + & .072 \\
\hline $29 \cdot 5$ & . . 000 & $29^{\cdot} .5$ & + & .067 \\
\hline 29 & -.005 & $29^{\circ}$ & + & .062 \\
\hline $28 \cdot 5$ & -.01 & $28 \cdot 5$ & + & .057 \\
\hline
\end{tabular}

But if the inside diameter of the tube be larger at one end than at the other, the corrections cannot be found by the preceding rule; but by the following method they may be obtained, with the same precision as before.

Fill about five or six inches of the sealed end of the tribe with quicksilver; and after having determined the attitide of the surface of the mercury in the cistern, pour that which is in the tube into it, and measure how high the surface of the fluid has been raised. Then divide this rise in the cistern by the number of inches of mercury poured into it, from the tube, and the quotient will be the correction for one inch rise of the mercury above the zero.

Suppose the number of inches of gnicksilver in the tubo yere, five, and this quantity raised the surface of the fluid in the cistern 5-100dths of an inch, then the correction would be 1-100dth of an inch, for every inch rise of the mercury above the zero; from whence all the other corrections may be found.

If the numbers found by these rules were engraved upon the plate of the instrument, in some form like Table 2 , or wriften upon a slip of paper and pasted upon the frame, the altitude of the quicksilver in the tube might then be corrected by inspection, and perhaps to as great a degree of precision as by any other method.

$$
\begin{aligned}
& \text { I am, sir, } \\
& \text { Lynu, Nov. 13, 1812. Your obedient servant, } \\
& \text { Ez. W WLKER. }
\end{aligned}
$$

LVIII. On Tests for Arsenic. By P. M. Roget, M.D.

To Mr. Tilloch,

SIR, $I_{T}$ is with reluctance that $I$ again trouble you on a subject in which the public is so little interested, as the eontroversy respecting the priority of Dr. Marcet or Mr. 